\title{
A USUCAPIÃO ESPECIAL URBANA COMO INSTRUMENTO DE REGULARIZAÇÃO FUNDIÁRIA PLENA: DESAFIOS PARA UM GIRO HERMENÊUTICO RUMO À NOVA ORDEM JURÍDICO-URBANÍSTICA
}

\section{SPECIAL URBAN USUCAPION AS AN INSTRUMENT OF FULL LAND REGULARIZATION: CHALLENGES FOR A HERMENEUTICAL TURN TOWARDS THE NEW URBAN-LEGAL ORDER}

\author{
Thiago de Azevedo Pinheiro Hoshino \\ Bruno César Deschamps Meirinho \\ Luana Xavier Pinto Coelho ${ }^{3}$
}

\section{Resumo}

A despeito de expressamente prevista na Constituição de 1988, a usucapião especial urbana tem sido objeto de importantes dissidências doutrinárias e jurisprudenciais, sobretudo em sua modalidade coletiva, conforme disciplinada pelo Estatuto da Cidade. Neste cenário, o presente trabalho intenta uma aproximação teórico-pragmática das dificuldades de operacionalização deste instrumento de regularização fundiária em assentamentos precários, a partir de estudos de caso de duas ações judiciais referentes à Vila Sabará e à comunidade Barracão. É possível vislumbrar, em ambas as experiências de assessoria jurídica popular, as dificuldades do Poder Judiciário para administrar conflitos dessa natureza e envergadura, além das imprecisões conceituais envolvendo os requisitos para a aquisição originária, as responsabilidades pela urbanização e parcelamento das áreas de interesse social e instituto do condomínio especial. Sugerem-se, ao final, interpretações alternativas para dirimir tais impasses e desburocratizar o acesso à justiça em nome da concretização do direito à cidade.

Palavras-chave: assentamentos precários; usucapião especial; regularização fundiária; condomínio de interesse social; direito à cidade

\begin{abstract}
Although expressly provided by the 1988 Constitution, special urban adverse possession has been the object of important doctrinal and jurisprudential dissent, especially in its collective modality, as disciplined by the City Statute. In this scenario, the present work attempts a theoretical-pragmatic approach to the difficulties of operationalizing this land regularization instrument in precarious settlements, based on case studies of two lawsuits concerning Vila Sabará and the Barracão community. It is possible to envisage, in both experiences of public interest law, the difficulties of the Judiciary to manage conflicts of this nature and scope, in addition to the conceptual inaccuracies involving the requirements for the original acquisition, the responsibilities for urbanization and the subdivision of areas of social interest and special condominium institute. In the end, alternative interpretations are suggested to resolve these impasses and to debureaucratize access to justice in the name of realizing the right to the city.

\footnotetext{
${ }^{1}$ Doutorando em Direito do Estado pelo Programa de Pós-Graduação em Direito da Universidade Federal do Paraná UFPR. Pesquisador do Núcleo de Estudos em Direito Administrativo, Ambiental e Urbanístico (PROPOLIS/PPGD-UFPR), do INCT Observatório das Metrópoles e do Grupo de Pesquisa em Arquiteturas do Sul - MALOKA. E-mail: hoshino.thiago@gmail.com

2 Mestre em Geografia - Produção e Transformação do Espaço Urbano-Regional pela Universidade Federal do Paraná. Pesquisador do Instituto Democracia Popular. E-mail: brunomeirinho@gmail.com

3 Mestre em Cooperação Internacional e Desenvolvimento Urbano pela TUD Darmstadt/Alemanha. Email: luanacoelho@terradedireitos.org.br
} 
Keywords: precarious settlements; special adverse possession; land regularization; condominium of social interest; Right to the city

\section{INTRODUÇÃO: A INFORMALIDADE FUNDIÁRIA E SUA CONFORMAÇÃO JURÍDICA}

Os assentamentos urbanos irregulares ou informais, por onde quer que se desenvolvam, apresentam-se de múltiplas formas. Sua proliferação e diversidade de idiossincrasias nos levam a questionar a informalidade como regra ou exceção no processo de urbanização brasileira.

A oposição entre o estado das cidades brasileiras e aquilo que projetam as normas para o espaço urbano é um grande desafio do urbanismo e do direito urbanístico contemporâneos. A norma, no momento de sua aplicação, busca, de um só lance, ajustar a realidade do mundo da vida e a ele ajustar-se, confluência de que extrai sua eficácia.

O padrão de expansão precária das cidades, em contrariedade às normas (tanto técnicas como jurídicas), característica que dá origem aos assentamentos irregulares ou informais, não é privilégio brasileiro. Para DAVIS (2006), a predominância da informalidade no dito "terceiro mundo", nos países emergentes ou em desenvolvimento, revela um fenômeno global, que autoriza o diagnóstico de um Planeta Favela.

Sobre a caracterização dos assentamentos informais, encontramos em Edesio Fernandes (2011, p.2) um olhar especializado sobre a situação latino-americana, com a seguinte definição:

Os assentamentos informais geralmente não têm escrituras legais formais e podem apresentar padrões de desenvolvimento irregular, falta de serviços públicos essenciais, como saneamento, e ocorrem em terrenos públicos ou ambientalmente vulneráveis. Estejam eles em terrenos públicos ou privados, os assentamentos informais cresceram progressivamente em muitos anos e vários existem há décadas. (grifos nossos)

Esta definição geral nos orienta ao exercício específico de identificar e dimensionar a informalidade a partir de casos concretos. Deste exercício, encontra-se uma tipologia de assentamentos razoavelmente consolidada, no caso brasileiro, a qual se presta a subsidiar a avaliação e formulação das políticas públicas neste campo. Uma classificação adotada com relativo sucesso pelos diagnósticos oficiais em múltiplas escalas federativas no Brasil é que designa os assentamentos como: cortiços, favelas, loteamentos irregulares ou clandestinos e conjuntos habitacionais degradados (BRASIL, 2010, p. 19 e 49). Note-se, todavia, que, na 
experiência brasileira, a expressão "favelas" é alternada com a designação genérica de "ocupações irregulares", preferida, por exemplo, na redação de documentos como o Manual da Regularização Fundiária Plena (BRASIL, 2007a, p. 89).

Esta classificação se mune, sobretudo, do processo de produção do espaço que deu origem à irregularidade. Sua adoção como referência para as políticas públicas é útil uma vez que, tendencialmente, as características da origem e da ocupação são determinantes para a definição das ações que podem promover a sua regularização. Como exemplo, as ocupações irregulares geralmente resultam da ação coletiva de moradores que ocupam, em regra espontaneamente, e se apropriam de uma gleba urbana - imóvel público ou privado - que se encontrava ociosa, vazia ou subutilizada (BRASIL, 2007a, p. 89). Sua regularização passa pela adoção de medidas de urbanização, parcelamento do solo e de titulação dos imóveis em favor dos ocupantes.

Origem distinta têm os loteamentos irregulares ou clandestinos, que geralmente resultam da venda sucessiva de lotes promovida pelo proprietário ou por terceiros à revelia do poder público, a partir de projetos implantados em contrariedade com a autorização estatal, ou ainda loteamentos sem infraestrutura básica implantada, cuja comercialização, ocupação e edificação ocasionam irregularidades perante as normas de regência de parcelamento do solo urbano (Lei 6.766/1979) e afins. Conforme o estágio de consolidação e urbanização do parcelamento, bem como da modelagem dos negócios jurídicos entabulados, são suficientes as medidas de regularização já previstas no art. 50 do referido diploma, cuja tutela, tradicionalmente, é de caráter mais consumerista.

Com efeito, as soluções são casuísticas e distintas. A relevância desta classificação não retira a validade de outras abordagens em relação aos assentamentos informais, como, por exemplo, as abordagens relativas aos seus aspectos físicos, aspectos atinentes à morfologia do assentamento, à qualidade da sua infraestrutura, suas características ambientais, etc.

No entanto, importante observar que a expressão "favela" tem um uso e significado histórico ${ }^{4}$, associado a ocupações densas, típicas de acampamentos de barracos que, originalmente, tinham características provisórias, e, com o tempo, ganham características permanentes. Mesmo com a transformação dos "barracos" e construções provisórias em edificações permanentes, esses assentamentos preservam as características urbanísticas morfológicas que possuíam na origem, ou seja, preservam caminhos que só podem ser trilhados

\footnotetext{
${ }^{4}$ Para uma leitura historiográfico do fenômeno, conferir: VALLADARES, 2005; CAMPOS, 2005.
} 
a pé e a proximidade entre as unidades habitacionais, entre outras características físicas. Estas características definem o que se chama "morfologia" do assentamento.

Para não confundir morfologia com processo de formação do assentamento, o Ministério das Cidades tem preferido adotar a denominação "ocupações irregulares", em lugar de "favelas", uma vez que diversas ocupações espontâneas de imóveis vazios não apresentam, necessariamente, a morfologia típica das favelas, embora seu processo de formação seja semelhante: ocupação espontânea de imóvel vazio.

Deste modo, quando se passa a implantar ações para a regularização fundiária de um assentamento, o primeiro passo a se colocar em prática é a caracterização do assentamento, que, dentre outras análises, deve procurar caracterizá-lo entre uma das tipologias propostas quanto ao processo de formação (BRASIL, 2007a, p. 20, e 2010, p. 19 e 49).

É precisamente para descrever este exercício, e sua possível solução por meio do instrumento da usucapião, que passaremos à descrição de dois casos concretos que assumiram emblematicidade no Município de Curitiba, a partir da atuação de assessorias jurídicas populares ao lado de comunidades reivindicadoras dos direitos à moradia digna e à cidade. Em ambos, lançou-se mão da usucapião especial urbana coletiva como instrumento de regularização fundiária, intento que, em olhar retrospectivo, merece agora disseminação e avaliação crítica verticalizada.

A análise das decisões judiciais nos casos escolhidos, assim como as dinâmicas processuais, nos permite avaliar de que forma o Poder Judiciário encontra-se preparado (ou não) para enfrentar o desafio que Ihe foi colocado pelo Estatuto da Cidade, de ser também um órgão responsável por reconhecer a posse para fins de moradia e mediar a realização a regularização fundiária.

Antes, todavia, uma observação é imperativa: ao tempo de formulação deste artigo, ainda se achava em vigor a Lei $11.977 / 2009$, razão pela qual não se enfrentam, aqui, as inúmeras controvérsias acerca da novel MPV 759/2016. Apesar das críticas já dirigidas ao diploma e partilhadas pelos autores, as quais denotam importante retrocesso no marco normativo da regularização fundiária, entendemos que os questionamentos centrais enfrentados no presente trabalho permanecem pertinentes ${ }^{5}$.

\footnotetext{
${ }^{5}$ Inclusive porque existem dispositivos na redação original da Medida Provisória (como os ats. 80 e 31) que, em tese, permitem interpreter que o dever de regularização fundiária plena com urbanização pelo Poder Público continua existindo, muito embora sua operacionalização reste bastante prejudicada com as alterações legais promovidas e não haja certeza sobre como elas serão consolidadas no Legislativo:
} 


\section{A EXPERIÊNCIA DAS MORADIAS SABARÁ E A OPERACIONALIZAÇÃO DA USUCAPIÃO COLETIVA COMO INSTRUMENTO DE REGULARIZAÇÃO FUNDIÁRIA}

As "Moradias Sabará" consistem em um complexo de vilas urbanas situado no bairro da Cidade Industrial de Curitiba. Embora seja formado por vários assentamentos contíguos, cada qual com seu nome próprio - como Vila Esperança, Vila Nova Conquista, Vila Eldorado, Vila Cruzeiro do Sul, etc. - o conjunto é designado "Sabará" tanto pelos moradores como pelos órgãos municipais.

Três vilas integrantes do Sabará - Esperança, Nova Conquista e Eldorado - foram escolhidas para realização de projeto de regularização fundiária sustentável coordenado pela Organização de Direitos Humanos Terra de Direitos, no ano de 2005. A experiência hora analisada foi, à época, apoiada pelo Ministério das Cidades, e dá ensejo a uma série de ponderações capazes de retroalimentar o debate para o aperfeiçoamento do instrumento em si.

Diga-se desde logo, as Vilas Esperança, Nova Conquista e Eldorado são resultantes de ocupações espontâneas realizadas no final da década de 1980 sobre glebas vazias situadas na Cidade Industrial de Curitiba. Pelas características do processo de formação, estes assentamentos foram classificados como ocupações irregulares.

Adicionalmente, é necessário identificar o domínio das glebas ocupadas, ou seja, se o assentamento se formou sobre imóveis de domínio público ou particular, uma vez que esta característica também influencia nas possíveis medidas para regularização.

No caso em análise, o levantamento da cadeia dominial concluiu que parte dos imóveis pertencia a uma sociedade de economia mista municipal, denominada Curitiba S/A, responsável pela implantação e urbanização da Cidade Industrial de Curitiba, sendo outra parcela de dominialidade particular, com alguns imóveis, inclusive, sem proprietário identificado. Uma

\footnotetext{
“Art. 8o Ficam instituídas normas gerais e procedimentos aplicáveis, no território nacional, à Regularização Fundiária Urbana - Reurb, a qual abrange medidas jurídicas, urbanísticas, ambientais e sociais que visam à regularização de núcleos urbanos informais. (...)

Art. 31. Na Reurb-S, caberá ao Poder Público competente, diretamente ou por meio da administração pública indireta, implementar a infraestrutura essencial, os equipamentos comunitários e as melhorias habitacionais, previstas nos projetos de regularização, e arcar com os ônus de sua manutenção.

$\S 1$ 을 Quando a área a ser regularizada for de titularidade de ente público, poderá ser celebrado ajuste entre o seu titular e o Município promotor para fins de implementação da infraestrutura essencial de equipamentos comunitários e de melhorias habitacionais, previstas nos projetos de regularização fundiária.

§ 2o As ações previstas no caput poderão ser realizadas durante ou depois de concluída a Reurb."
} 
estreita faixa da ocupação, ainda, integrava o patrimônio da Companhia de Habitação Popular de Curitiba - COHAB/CT.

Considerando que a usucapião encontra vedação constitucional para ser promovida sobre imóveis públicos, mas é admitida pela jurisprudência dos tribunais superiores sobre bens de sociedades de economia mista (STJ - RESP 120702-DF DJ 28/06/2001, STJ - REsp 647357 DJ 23/10/2006) ${ }^{6}$ e, ainda, sobre bens sem domínio definido (STJ - REsp 113255-MT DJ 08/05/2000, REsp 674558-RS DJ $26 / 10 / 2009)^{7}$, os assentamentos em análise foram caracterizados como ocupações irregulares sobre imóveis particulares, sujeitos, ao tempo de início do projeto (2006), desde longa data, à prescrição aquisitiva.

\section{Das dimensões inarredáveis da regularização fundiária}

As Vilas Esperança, Nova Conquista e Eldorado demandavam, prioritariamente, a regularização fundiária referente à titulação dos imóveis em favor de seus moradores. De acordo com as normas urbanísticas, para que se faça a titulação individual dos imóveis é necessário que se proceda à individualização dos terrenos por meio da operação de parcelamento do solo, a qual envolve etapas de urbanização.

A urbanização abrange também intervenções de implantação de infraestrutura e garantia de acesso aos serviços públicos urbanos. No entanto, após cerca de 20 anos de existência, os assentamentos em questão conquistaram diversos melhoramentos físicos através

\footnotetext{
${ }^{6}$ STJ - RESP 120702-DF. EMENTA: USUCAPIÃO. Sociedade de Economia Mista. CEB. O bem pertencente a sociedade de economia mista pode ser objeto de usucapião. Precedente. Recurso conhecido e provido. (REsp 120702/DF, Rel. Ministro RUY ROSADO DE AGUIAR). STJ - RESP 647.357 - MG EMENTA: RECURSO ESPECIAL. AÇAO REIVINDICATÓRIA. USUCAPIAO EXTRAORDINÁRIO. MATÉRIA DE DEFESA. BEM PERTENCENTE A SOCIEDADE DE ECONOMIA MISTA. POSSIBILIDADE. I Entre as causas de perda da propriedade está o usucapião que, em sendo extraordinário, dispensa a prova do justo título e da boa-fé, consumando-se no prazo de 20 (vinte) anos ininterruptos, em consonância com o artigo 550 do Código Civil anterior, sem que haja qualquer oposição por parte do proprietário. (STJ - RESP 647.357 - MG, Rel Ministro CASTRO FILHO).

${ }^{7}$ STJ - REsp 113255-MT. EMENTA: Civil. Usucapião. Alegação, pelo Estado, de que o imóvel constitui terra devoluta. A ausência de transcrição no Ofício Imobiliário não induz a presunção de que o imóvel se inclui no rol das terras devolutas; o Estado deve provar essa alegação. Precedentes do Supremo Tribunal Federal e do Superior Tribunal de Justiça. (...) (REsp 113255/MT, Rel. Ministro ARI PARGENDLER).STF - RE 86234-MG. EMENTA: Usucapiao. Alegação de estado membro de que cabe ao usucapiente o ônus da prova de que a gleba em causa não é terra devoluta, não bastando, para comprová-lo, o depoimento de testemunhas e a existência de indícios. Inexiste em favor do Estado a presunção iuristantum que ele pretende extrair do art. 3 da Lei 601, de 18 de setembro de 1850. Esse texto legal definiu, por exclusão, as terras públicas que deveriam ser consideradas devolutas, o que é diferente de declarar que toda gleba que não seja particular é pública(...). Cabia, pois, ao estado o ônus da prova de que, no caso, se tratava de terreno devoluto. Recurso extraordinário não conhecido. (RE 86234, Rel. Ministro MOREIRA ALVES).
} 
da organização comunitária, já possuindo, em grande medida, a infraestrutura básica necessária, sendo a formalização do assentamento a maior demanda represada.

Durante a fase de leitura e planejamento participativo do projeto, concluiu-se que a regularização destas vilas deveria abranger, tanto ações de urbanização, como de titulação dos imóveis objetos de posse. A condução simultânea de ambas nem sempre é possível ou aconselhável, uma vez que são distintos os sujeitos que participam de cada uma destas dimensões, e, consequentemente, os conflitos e suas mediações.

A titulação, frequentemente, trata da relação entre o ocupante/possuidor de fato do imóvel e o seu proprietário formal. A pretensão de regularização pode colidir com ações de reintegração de posse já em trâmite ou conflitos de natureza negocial (de compra e venda, por exemplo) entre as partes. Tais controvérsias, algumas vezes consideradas estritamente privadas, podem ser melhor compostas sob a tutela do poder público, em um processo de regularização fundiária que pondere o direito à moradia dos ocupantes em relação à função social da propriedade urbana, amiúde não atendida.

A urbanização, por outro lado, dirige-se às condições materiais de existência e habitabilidade do assentamento, mitigando riscos e superando precariedades. À parte isso, cuida, ainda, da adequação ao plano diretor municipal, às leis de zoneamento ou de uso e ocupação do solo, às normas ambientais, etc., requerendo, grosso modo, uma mediação travada entre os moradores/beneficiários e os órgãos públicos (de licenciamento, a Câmara de Vereadores, os conselhos da cidade e de meio ambiente, entre outros atores). Desde esta compreensão, assinala Raquel Rolnik:

O termo "regularização" tem sido usado pelas diversas municipalidades com sentidos diferentes, referindo-se em muitos casos somente à urbanização das áreas informais, isto é, aos programas de implementação de obras de infraestrutura urbana e prestação de serviços públicos. Em outros casos, o termo é usado para se referir tão-somente às políticas de legalização fundiária das áreas e dos lotes ocupados informalmente. Algumas experiências mais compreensivas tentam combinar, em alguma medida, essas duas dimensões fundamentais, quais sejam, urbanização e legalização. São ainda mais raros os programas que têm se proposto a promover a regularização das construções informais. (BRASIL, 2007b, p. 21)

Portanto, é fundamental uma visão integrada entre as medidas de urbanização stricto sensu e de titulação. Por outro lado, esta multidimensionalidade não deve ser confundida com a prática ainda corrente de se anteporem impedimentos mútuos entre as vertentes urbanísticoambiental e dominial, asfixiando o processo como um todo. Há que se atentar, como alerta, para precedentes judiciais que, com fulcro exclusivamente em restrições urbanístico-ambientais 
que, em si, extrapolam o objeto da lide in concreto, denegam o acesso à terra pela via da usucapião especial ${ }^{8}$.

Tal entendimento desnatura o instituto em sua essência, posto que, na maioria absoluta dos casos, as construções levadas a cabo em assentamentos informais acham-se em desacordo com os padrões urbanísticos locais. Fazer vingar essa postura seria suficiente para sepultar a usucapião especial urbana, mormente na modalidade coletiva. Em suma, explicita-se que na ausência de adequada visão holística das medidas de regularização fundiária, pode-se chegar ao resultado totalmente indesejado de obstruir-se a titulação do imóvel em favor dos legítimos possuidores em virtude de características morfológicas do assentamento, matérias tecnicamente não alegáveis em sede de usucapião especial urbana, cujo rol de requisitos objetivos e subjetivos é taxativo.

Reconhecendo que a regularização fundiária de assentamentos informais deve concatenar diversas medidas cadenciadas com vistas a assegurar o direito à moradia dos seus ocupantes, a Lei 11.977 de 7 de julho de 2009 definiu, em seu art. 46:

Art. 46. A regularização fundiária consiste no conjunto de medidas jurídicas, urbanísticas, ambientais e sociais que visam à regularização de assentamentos irregulares e à titulação de seus ocupantes, de modo a garantir o direito social à moradia, o pleno desenvolvimento das funções sociais da propriedade urbana e o direito ao meio ambiente ecologicamente equilibrado.

No entanto, com vistas a prevenir contradição entre as abordagens, resultando na frustração dos instrumentos de securitização da posse, como a usucapião especial e a

8 "EMENTA: DIREITO CIVIL, AMBIENTAL E AGRÁRIO. APELAÇÃO. USUCAPIÃO ESPECIAL URBANA. IRREGULARIDADE DA PLANTA DO IMÓVEL. AUSÊNCIA DE CITAÇÃO. SUPERAÇÃO DA QUESTÃO. EXAME DO MÉRITO. EFEITO DEVOLUTIVO EM PROFUNDIDADE. IMÓVEL EM ÁREA RURAL. USUCAPIÃO ESPECIAL URBANA. PRESCRIÇÃO AQUISITIVA NÃO VERIFICADA. ÁREA DE PRESERVAÇÃO PERMANENTE (MANANCIAL). ANÁLISE DA POSSE SEGUNDO A CORRENTE CIVILISTA (SAVIGNY E JHERING): DESDOBRAMENTO DA PROPRIEDADE. LEI AMBIENTAL. LIMITAÇÃO A 10.000 M2 E USO DE 10\% PARA UMA UNIDADE FAMILIAR. FRACIONAMENTO COM ÁREA DE 250M2. AUSÊNCIA DO PODER DE USO. POSSE NÃO CARACTERIZADA. ANÁLISE DA POSSE SEGUNDO A CORRENTE FUNCIONALISTA (SALEILLES, PEROZZI E GIL): FENÔMENO DE UTILIDADE SOCIAL. FUNÇÃO SOCIAL E FUNÇÃO AMBIENTAL (SOCIOAMBIENTAL). CONFLITO COM A MANUTENÇÃO DO EQUILÍBRIO ECOLÓGICO LOCAL. FUNÇÃO AMBIENTAL NÃO ATENDIDA. AUSÊNCIA DE POSSE. IMPROCEDÊNCIA DA USUCAPIÃO, POR ECONOMIA PROCESSUAL. DESNECESSIDADE DE ANULAÇÃO DA SENTENÇA. RECURSO ACOLHIDO. (...) 7. A instalação de uma vila de moradores, com cerca de 270 ocupantes de áreas individuais de $250,00 \mathrm{~m} 2$, individualmente menor que a de fracionamento mínimo imposta por lei local $(10.000,00 \mathrm{~m} 2)$ e de ocupação máxima (10\%), situada em zona de manancial (APP), onde a princípio somente seria permitida a ocupação de uma unidade familiar, não contribui para a manutenção do equilíbrio ecológico local, não cumprindo a função socioambiental da posse, à luz da teoria funcionalista (Saleilles, Perozzi e Gil), não caracterizando posse suscetível de gerar aquisição da propriedade por usucapião especial urbana e, uma vez ausente o elemento caracterizador da posse, inviável o reconhecimento da usucapião especial urbana." (TJPR. 18a Câmara Cível. Apelação Cível n. 812510-8. Relator: Juiz Substituto de 2o Grau Francisco Jorge. Julgamento: 23/11/2011) 
Concessão de Uso Especial para fins de Moradia, a Lei 11.977/2009 também deixa claro que as medidas podem ser executadas em tempos distintos, isto é, em etapas, sem a necessidade da precedência de uma pela outra ou da simultaneidade entre elas. Sabiamente, o legislador dispensou, para o registro da sentença declaratória de usucapião, o projeto de regularização fundiária a que alude o art. 51:

Art. 47. Para efeitos da regularização fundiária de assentamentos urbanos, consideram-se: (...)

IX - etapas da regularização fundiária: medidas jurídicas, urbanísticas e ambientais mencionadas no art. 46 desta Lei, que envolvam a integralidade ou trechos do assentamento irregular objeto de regularização. (...)

Art. 51. O projeto de regularização fundiária deverá definir, no mínimo, os seguintes elementos: (...)

$\S 1$ ㅇ O projeto de que trata o caput não será exigido para o registro da sentença de usucapião, da sentença declaratória ou da planta, elaborada para outorga administrativa, de concessão de uso especial para fins de moradia. (...)

§ 3ㅇ A regularização fundiária pode ser implementada por etapas.

Desta leitura se depreende que a regularização fundiária pode ser executada em etapas, iniciando pela titulação, na modalidade coletiva, que será posteriormente individualizada por meio da posterior urbanização. Nesse passo, uma medida não se torna obstáculo para a outra, ao contrário, são complementares e integradas, sendo executadas de forma sequencial, admitida a possibilidade de serem executadas também de forma simultânea. Sem embargo, deve-se zelar pela transdisciplinaridade numa intervenção desta monta e com tamanha repercussão social, como recorda NALINI (2011, p. 170):

A pretensão é urgente e muito mais abrangente do que apenas pensar em regularização fundiária sob a vertente jurídica. Integram essa política programas quais a urbanização e a regularização de favelas, recuperação e prevenção de áreas sujeitas a riscos de desmoronamento, urbanização e regularização de loteamentos ilegais, reforma e/ou ampliação de moradias resultantes do processo de autoconstrução, recuperação de áreas de preservação ambiental ocupadas por moradias, reforma de cortiços e requalificação urbanísticas de áreas centrais degradadas, tudo a envolver profissionais de áreas diversas, além do terceiro setor e poder público.

Essa preocupação em realizar a regularização fundiária plena, e não somente o reconhecimento da propriedade através da titulação, é um desafio que cabe também ser enfrentando no resultado na decisão coletiva. 


\section{Da opção pela usucapião coletiva e do requisito da não-individualização da posse}

Tendo em vista o acesso à justiça e a economia processual, o projeto de regularização fundiária das vilas do Sabará optou por, primeiramente, promover a titulação coletiva dos imóveis para, posteriormente, proceder, por meio do poder público municipal, a urbanização das áreas, com a individualização dos terrenos.

No caso, julgou-se ser mais prudente e eficiente dar início à regularização por meio uma ação coletiva que resolvesse a questão da titulação dos imóveis, assegurando à comunidade o pleno domínio da gleba.

Desta forma, com o domínio coletivo da gleba, estaria resolvida qualquer pendência, conflito ou reivindicação do imóvel por parte de antigos proprietários que abandonaram as glebas. Após a manifestação judicial em sentido favorável à comunidade, a etapa posterior seria a da urbanização, na forma do art. 10, §4ㅇ da Lei n. 10.257/2001 - Estatuto da Cidade.

Do contrário, caso se procedesse à urbanização dos imóveis para a posterior propositura de ações de usucapião, o tumulto processual seria evidente. O conjunto das três vilas objetos do projeto de regularização soma, aproximadamente, 1.000 famílias, de forma que a propositura de ações de usucapião individual resultaria em um grande número de processos. Por esta razão, a opção pela medida coletiva neste caso se mostra muito favorável tanto para o funcionamento da justiça, como para os administrados.

Durante o trabalho técnico-social que precedeu à propositura da ação de usucapião coletiva, realizou-se também uma série de ações multidisciplinares para a produção de um projeto popular de urbanização, de modo que grande parte dos requisitos formais atinentes à futura urbanização já foram produzidos durante a etapa preparatória da própria usucapião, optando-se por iniciar pela titulação para a posterior urbanização pela própria decorrência da redação do Estatuto da Cidade, e pela razão já exposta, quanto à eficiência na administração da justiça.

Segundo o art. 10 do Estatuto da Cidade, a usucapião coletiva pode ser promovida nas ocupações onde não for possivel identificar os terrenos ocupados por cada possuidor. O requisito da impossibilidade de identificação dos terrenos tem sido considerado pela doutrina como uma exigência a ser interpretada de forma flexível, com vistas aos objetivos da regularização fundiária, e não para criar obstáculos ao exercício do direito, uma vez que, em última análise, sempre seria possível identificar, em algum grau, os limites da moradia de cada 
família (LOUREIRO, 2004, p. 96/97; SAULE, 2004, p. 390), neste sentido, explica Betânia Alfonsin:

A expressão "onde não for possível identificar os terrenos ocupados por cada possuidor" deve ser lida de forma a abarcar a forma de ocupação de solo típica das favelas, em sua maioria desordenadas e densas. Em verdade, com a tecnologia existente hoje em dia, para fins de levantamento topográfico e cadastral, praticamente não há favelas onde não seja possível identificar os lotes. Assim, para que o dispositivo seja eficaz e atenda ao "espírito da lei", será necessário flexionar a interpretação para permitir que - em se tratando de favelas - possam ser regularizadas de forma coletiva. (BRASIL, 2007b, p. 94)

Destarte, segundo a doutrina, é preciso haver a admissão ampla do requisito do art. 10

do Estatuto da Cidade, evitando-se leituras restritivas com relação à impossibilidade de identificação dos lotes individualmente. Mesmo porque a jurisprudência de determinados tribunais tem descartado a usucapião especial urbana na modalidade individual como meio hábil para a aquisição de quinhões de gleba ainda não formalmente parcelada, como preconizam julgados da Corte de Justiça Paulista ${ }^{9}$.

Embora não se vislumbre razoabilidade nas decisões decalcadas, pela exigência que fazem de prévio e regular parcelamento do solo - requisito este não constante da Lei $\mathrm{n}$.

\footnotetext{
9 “EMENTA: Usucapião coletiva - Ação proposta pela União de Moradores da Comunidade Porto Seguro Possibilidade de propositura da usucapião coletiva por pessoa jurídica, nos termos do disposto no artigo $\underline{12}$ do Estatuto da Cidade - Pleito formulado na petição inicial que engloba apenas parte do loteamento irregular denominado Jardim Tricolor -Impossibilidade de divisão do loteamento em partes para declarar a usucapião especial sobre parcelas individualizadas - Via da usucapião especial urbana que deve ser utilizada apenas para englobar todo o loteamento irregular - Inadequação da via eleita para o objetivo almejado - Indeferimento da petição inicial mantido. Nega-se provimento ao recurso, com observação." (TJSP. 5a Câmara de Direito Privado. Apelação Cível n. 9068968902004826. Relatora: Desembargadora Christine Santini. Julgamento: 16/03/2011) "EMENTA: USUCAPIÃO ESPECIAL - Imóvel urbano - $\mathrm{O}$ apelante pretende usucapir lote de terreno em loteamento clandestino - Lote situado em área que não foi objeto de regular parcelamento de solo - O lote tem 112,97 m2, área inferior ao do módulo urbano - 0 art.183 da Constituição Federal, prevê o usucapião especial urbano de imóvel urbano com área de até $250 \mathrm{~m} 2$, àquele que o possuir de maneira ininterrupta e sem oposição, por cinco anos, desde que não seja proprietário de outro imóvel urbano ou rural - 0 art. 182 da Lei Maior estatui que o parcelamento do solo urbano deve atender as exigências do plano diretor, tendo em vista a ordenação da cidade, como política de desenvolvimento e de expansão urbana - O art. 4a da Lei 6.766/79 impõe requisitos mínimos para o parcelamento do solo urbano, entre os quais área mínima de $125 \mathrm{~m} 2$ Interpretação sistemática - Não pode ser admitido usucapião especial urbano de modo contrário ao regramento do parcelamento do solo, previsto na própria Constituição, na lei federal que regula o tema e na lei municipal que estabelece o módulo urbano - O usucapião não é via adequada à regularização de loteamento clandestino - À falta de matrícula, não é possível o registro de sentença que concedesse o usucapião - Configurada a inutilidade do provimento jurisdicional pleiteado - Sentença mantida - Recurso improvido." (TJSP. 1ạ. Câmara de Direito Privado. Apelação Cível n. 990.10.378810-9. Relator: Des. Paulo Eduardo Razuk. Julgamento: 10. de fevereiro 2010)

"EMENTA: USUCAPIÃO - O usucapião não é o meio apropriado para regularização de loteamento clandestino e sim modo de aquisição de propriedade pela posse animus domini. Recurso provido para julgar improcedente a ação." (TJSP - Apelação Cível n 84.792-4 - Rei. Ênio Zulianni - 27.07.99 - V.U.).
} 
10.257/2001 - as mesmas suscitam a necessidade de se fortalecer o instrumento em sua potencialidade coletiva. Os julgados conduzem, ainda, ao debate sobre a relação entre a Lei n. 6.766/1979 e o Estatuto da Cidade.

Para que fique mais claro o sentido desta interpretação ampla da impossibilidade de identificar os lotes, reiteramos os fundamentos já apresentados anteriormente, de que a usucapião e a urbanização consistem em etapas distintas e integradas da regularização fundiária.

De acordo com o Estatuto da Cidade, após a usucapião coletiva, a comunidade poderá receber a urbanização, da qual resultará a individualização e identificação dos lotes de cada família. Portanto, este requisito deve ser compreendido em seu sentido formal, pertinente às normas urbanísticas.

Os imóveis podem ser considerados bem indivisíveis enquanto não sejam submetidos às operações de parcelamento do solo, previstas pela Lei n. 6.766/79. Considerando que a divisão de uma gleba em lotes altera a sua substância, e sempre deve resultar de um processo de urbanização, o entendimento de que os bens imóveis são indivisíveis é coerente com o disposto no art. 87 do Código Civil. ${ }^{10}$

Assim sendo, antes de haver a urbanização, não é possível identificar os lotes ocupados por cada possuidor. Neste caso, a lei não está se referindo à morfologia da ocupação, isto é, não está se referindo à impossibilidade física de identificar a moradia de cada família, uma vez que isto sempre será possível.

A exigência do art. 10 do Estatuto da Cidade refere-se, isso sim, à impossibilidade formal de se proceder a esta individualização, enquanto não houver a urbanização, operação esta que será decorrente da sentença da usucapião.

Acreditamos que esta é a leitura sistemática e teleológica mais adequada para o disposto no art. 10 do Estatuto da Cidade, no que concerne à impossibilidade de identificar os lotes ocupados por cada morador.

As vilas do Sabará não possuem a morfologia característica das favelas, isto é, não apresentam caminhos estreitos e casas agrupadas. Pelo contrário, sua morfologia é característica de áreas urbanizadas, com ruas transitáveis e imóveis com testada para a via. No

\footnotetext{
${ }^{10}$ Art. 87. Bens divisíveis são os que se podem fracionar sem alteração na sua substância, diminuição considerável de valor, ou prejuízo do uso a que se destinam.
} 
entanto, seu processo de formação é típico de uma ocupação irregular, não havendo porque rejeitar a usucapião coletiva como via adequada à titulação e urbanização. ${ }^{11}$

\section{A EXPERIÊNCIA DA SOCIEDADE BARRACÃO E OS DESAFIOS PARA A IMPLEMENTAÇÃO DO INSTRUMENTO PÓS-SENTENÇA}

Outro caso emblemático de utilização da usucapião especial urbana na modalidade coletiva para garantir acesso à terra urbana a famílias de baixa renda é o da Sociedade Barracão em Curitiba. Trata-se de comunidade de catadores de material reciclável que, desde 1999, utilizam para fins de moradia e para a realização de sua atividade econômica, área abandonada de uma massa falida. O terreno, para o qual a empresa proprietária não deu qualquer destinação ao longo de anos a fio, tampouco exercendo atos de fiscalização ou manutenção, tornou-se objeto de disputa judicial após a propositura de Ação de Reintegração de Posse, somente em 2004. Com fundamento no art. 13 do Estatuto da Cidade foi invocado, como matéria de defesa, o atendimento aos requisitos para o reconhecimento da prescrição aquisitiva. Em 2013, o Tribunal de Justiça do Paraná confirmou a sentença proferida em primeiro grau, julgando procedente a usucapião coletiva urbana a favor da comunidade, em decisão inédita no Estado ${ }^{12}$, a qual robustece as possibilidades de emprego do instituto como instrumento de proteção ao direito à moradia digna em contextos de deflagrado conflito fundiário.

Dentre as matérias analisadas pelo Tribunal de Justiça do Estado do Paraná estão: a) a possibilidade da prescrição aquisitiva de imóvel de massa falida; e b) a função social da propriedade. Nesse sentido, dispõe o acórdão:

Ocorre que, a suspensão da prescrição à que se refere o artigo [6 da Lei 11.105/05] diz respeito apenas aos direitos e ações dos credores contra a massa e o falido, não atingindo os direitos e as obrigações de terceiros para com a massa falida.

A instauração do processo de falência, por si só não inibe a prescrição aquisitiva. Deve ser considerado que a suspensão da prescrição, quer na

\footnotetext{
${ }^{11} \mathrm{O}$ processo ainda se encontra na fase de instrução, com tramitação excessivamente lenta. Aguarda-se o resultado da perícia requerida pelo juiz para que o processo finalmente vá para sentença.

12 Há importantes precedentes em outros tribunais sobre a questão: "REIVINDICATÓRIA. EXCEÇÃO DE USUCAPIÃO CONSTITUCIONAL E COLETIVO. Ocupação de área superior a duzentos e cinqüenta metros quadrados, por famílias de baixa renda, com ânimo de dono, por tempo superior a cinco anos, sem oposição. art. 10, lei no 10.257/01 e art. 183, cf. prazo prescricional que passou a fluir a partir de 05.10.1988. Citação válida somente em 1997. Interrupção da prescrição. art. 219, do cpc. Exceção de usucapião acolhida." (Apelação Cível № 70004807566, Décima Nona Câmara Cível Tribunal de Justiça do RS, Relator: Des. CARLOS RAFAEL DOS SANTOS JUNIOR, Julgado em 10/06/2003).
} 
antiga lei de falências (DL n.o 7.661/45), quer na lei de recuperação (LF n.o 11.101/2005), diz respeito às obrigações do falido, que não se confundem com a prescrição aquisitiva.

(...)

A Constituição Federal tem, dentre seus objetivos, busca a redução das desigualdades sociais. Sem opor-se a garantia do direito de propriedade, não mais vigora o absolutismo de tal direito, dando amparo à socialização e à equitativa distribuição dos bens. Nesta esteira, o direito de propriedade subordina-se ao interesse coletivo, batizado de "função social".

No caso em tela, mostra-se praticamente inviável retirar tais famílias da área ocupada, tendo em vista a dignidade da pessoa humana e função social que transmitiram ao imóvel. As famílias ali assentadas passaram a viver no local, construindo moradias e desenvolvendo atividades para sobrevivência.

Posto isto, a função social da propriedade tem por finalidade o desenvolvimento social e o bem-estar dos habitantes.

Fato é que tais famílias encontram-se na área por mais de cinco anos, de forma ininterrupta e sem oposição. No decorrer deste tempo construíram casas e estabeleceram domicilio, sem oposição. (Tribunal de Justiça do Estado do Paraná, Apelação Cível no 917.511-7, julgamento: 30/01/2013).

A experiência, apesar do sucesso no manejo da usucapião coletiva por parte dos requeridos, ainda nos coloca inúmeros desafios, em especial no que concerne à gestão da propriedade no momento pós-sentença. A área é carente de urbanização, a situação de moradia é precária e há problemas quanto à densidade sobre o lote, bem como descompasso entre a atual conformação socioespacial do assentamento e os índices urbanísticos incidentes na região. No entanto, o município se tem eximido da responsabilidade de fornecer mesmo as condições mínimas de infraestrutura para a comunidade, sob a alegação de que a área seria privada, gerando para os moradores a obrigação de levar a cabo, por sua conta e risco, o processo de regularização fundiária.

\section{Da natureza jurídica do condomínio especial de interesse social}

É neste contexto que se faz essencial a análise do instituto do condomínio especial, que se constitui com a sentença declaratória de usucapião coletiva. O Estatuto da Cidade não se ateve a dispor pormenores sobre o funcionamento, o regime jurídico ou as condições de extinção desta figura inovadora, prevendo tão somente que:

Art. 10 (...) § 4ㅇ O condomínio especial constituído é indivisível, não sendo passível de extinção, salvo deliberação favorável tomada por, no mínimo, dois terços dos condôminos, no caso de execução de urbanização posterior à constituição do condomínio. 
Problemas desta natureza são enfrentados na prática, de modo que o vazio legislativo exige preenchimento doutrinário, quando ainda não jurisprudencial. Nesse cenário, limitar, em hermenêutica restritiva, o alcance e as potencialidades da usucapião coletiva pode comprometer seriamente a possibilidade de concretização dos direitos fundamentais de populações já submetidas a um árduo litígio judicial, a despeito da urgência de suas demandas mais básicas. O primeiro equívoco interpretativo, já anunciado, é a compreensão da propriedade coletiva adquirida por esta via, como similar a qualquer outra espécie de dominialidade privada, recusando-se, por tal motivo, o poder público a promover as melhorias ou investimentos necessários.

Em leitura sistemática, tal perspectiva induziria analogia com o regime jurídico dos condomínios edilícios previstos na legislação civil (Lei n. 4.591/64 e art. 1.314 e seguintes do Código Civil de 2002), o que, não obstante a proximidade de nomenclatura e alguns poucos pontos de contato, a própria doutrina tem demonstrado desarrazoado:

Em verdade, no "condomínio especial" da Lei n. 4.591/64, com as modificações apresentadas pelo Código Civil (arts. 1.331 a 1.358), referentes ao condomínio edilício, não se encarta o condomínio instituído pelo Estatuto da Cidade, porquanto neste, ao contrário do condomínio da Lei n. 4.591/64, não se pode falar em identificação de unidades autônomas atreladas à fração ideal do terreno. (...). Por sua vez, o condomínio comum do Código Civil também não encampa o destacado pelo Estatuto da Cidade, uma vez que pode ser extinto a pedido de qualquer dos condôminos, o que não ocorre no condomínio em estudo, visto não estar sujeito à extinção, salvo por deliberação qualificada dos condôminos, caso de execução de urbanização. Dessa forma, tem-se que o condomínio constituído em razão do usucapião coletivo é sui generis, haja vista que não se enquadra em nenhuma das espécies previstas no direito brasileiro (CORDEIRO, 2011, p. 243)

Uma das significativas distorções que o raciocínio analógico ensejaria seria a de se delegar ao cuidado unicamente dos moradores recém-proprietários a gestão e manutenção das áreas de uso comum e mesmo de logradouros públicos eventualmente integrantes da área usucapida, tais como ruas ainda não oficializadas e praças de fato.

É nítido, portanto, que o problema da atribuição de responsabilidade pelas áreas comuns não pode ser solucionado sob a ótica civilística, haja vista que a intentio legis, ao disciplinar apenas a modalidade coletiva de usucapião dentro de diploma urbanístico próprio (todas as demais encontram abrigo também no ambiente do direito civil convencional) vai justamente na contramão da privatização do espaço público que se verifica em empreendimentos como os loteamentos fechados. Dar ao condomínio especial do art. 10, §4으, da Lei n. 10.257/2001 o mesmo tratamento jurídico das demais espécies condominiais significa 
ignorar os valores que informam o Estatuto da Cidade e a disparidade entre as realidades materiais e os sujeitos nelas envolvidos. Caso desejasse igualá-los, a lei bem poderia ter feito remissão expressa ao condomínio civil.

Aqui, oportuno resgatar o primado da autonomia do Direito Urbanístico frente ao Direito Civil e, em igual extensão, aos Direitos Administrativo e Ambiental. Não se trata de compartimentalização excludente, mas da constatação de uma distinção operada pelo legislador constituinte, que, no art. 24, I, da Carta Magna brasileira, conferiu a este ramo independência, inclusive no tocante à repartição de competências federativas. Assim, forçoso assumir a disciplina urbanística como repertório de institutos, instrumentos e principiologia particulares.

Afastada a possibilidade de nos socorrermos, mesmo que analogicamente, do instituto do condomínio civil, inevitável concluir que o condomínio especial do Estatuto da Cidade é figura novel, cujo regime jurídico deve ser compreendido dentro das implicações da ordem urbanística vigente, e visando, sobretudo, atender às suas diretrizes fundamentais de garantia do direito à moradia adequada e do direito à cidade (art. 2으, I). No mesmo diapasão, qualquer interpretação que oponha obstáculos à efetivação de tais direitos, em prejuízo daqueles grupos vulneráveis que deveriam ser os beneficiários prioritários da prestação estatal, há que ser rechaçada, por inconstitucional.

Inúmeros outros questionamentos advêm da falta de clareza normativa, premindo os estudiosos e operadores do direito a partir em busca de um regime jurídico e de um alicerce teórico adequados para lastrear o instituto, amoldando-o aos imperativos da nova ordem urbanística ${ }^{13}$, assim palmilhada por Edésio Fernandes:

Para tanto, é preciso mudar o paradigma de interpretação. Estudar o Direito Urbanístico do Brasil do século XXI implica várias ordens de articulações básicas. A primeira é esse esforço sistemático e consistente de interpretação das leis urbanísticas à luz dos princípios próprios do Direito Urbanístico. A segunda é caminhar para além dessa dimensão interna do Direito no sentido da construção de uma hermenêutica para a interpretação dos princípios legais a partir da consideração da análise crítica dos processos de produção de leis. (FERNANDES in FERNANDES e ALFONSIN, 2006, p. 13)

13 “Esclareça-se que o aqui se está convencionando chamar de 'nova ordem jurídico-urbanística' está intimamente ligado à ruptura com aquela noção de propriedade imobiliária urbana que deitou raízes na tradição civilista brasileira anterior à Constituição de 1988. (...) Assim, como o paradigma constitucional democrático inaugura, como se viu em outros campos, o marco de uma nova ordem jurídico-urbanística, para a qual é estruturante, matricial mesmo, o princípio da função social da propriedade e da cidade. Em outras palavras, o direito de propriedade só é de ser garantido e legitimamente exercido se satisfeito $o$ condicionamento intrínseco do atendimento a uma função social." (MATTOS, 2006, p. 35-36) 
A partir do caso concreto da Sociedade Barracão - que se diferencia do projeto de regularização fundiária das Moradias Sabará pelo formato de emergência do conflito e pela exiguidade do prazo para que se pudessem elaborar previamente estudos urbanísticos evidenciam-se ao menos dois entraves de relevo, replicados em situações Brasil afora, passíveis de releitura nos marcos dessa nova ordem jurídico-urbanística:

a. a incompatibilidade entre os padrões urbanísticos locais (em particular, o lote mínimo de $450 \mathrm{~m}^{2}$ ) e a densidade habitacional do imóvel, cujas frações ideais individuais são bastante inferiores e implicariam, num procedimento tradicional de parcelamento do solo, diversos reassentamentos, contrários à própria intencionalidade do instrumento;

b. a indefinição sobre as responsabilidades (do Poder Público ou dos particulares) pela urbanização da área, causa extintiva do condomínio coletivo, na dicção do supracitado dispositivo estatutário, o que, necessariamente, abarca intervenções de ordem jurídica, urbanística, ambiental e social.

Quanto a esse aspecto, a harmonização da morfologia do assentamento com os parâmetros de uso e ocupação do solo previstos em regramento municipal, exige o esforço de apreciar teleologicamente a usucapião coletiva em sua feição de instrumento de regularização fundiária plena que autoriza, por isso mesmo, a instituição de normas especiais de urbanização, em consonância com o art. 2º, XIV do Estatuto da Cidade:

Art. 2A política urbana tem por objetivo ordenar o pleno desenvolvimento das funções sociais da cidade e da propriedade urbana, mediante as seguintes diretrizes gerais: (...)

XIV - regularização fundiária e urbanização de áreas ocupadas por população de baixa renda mediante o estabelecimento de normas especiais de urbanização, uso e ocupação do solo e edificação, consideradas a situação socioeconômica da população e as normas ambientais;

Em avaliação topológica, a inserção desta espécie de usucapião no bojo do Estatuto da Cidade reforça sua organicidade com as demais figuras jurídicas ali estipuladas. Obviamente, em homenagem ao princípio da justa distribuição dos ônus e benefícios da urbanização, o entendimento aplica-se de maneira direcionada, como vetor de justiça (re)distributiva, isto é, com recorte destacadamente socioeconômico. Neste viés, recomendável a associação do condomínio especial em tela com as Zonas Especiais de Interesse Social e suas congêneres, as quais representam exatamente o reconhecimento de um território de diferença no universo da cidade. Entre outros, Betânia Alfonsin enxerga na assimilação das ZEIS não apenas uma ferramenta operacional à regularização em si, mas à salvaguarda de seu objetivo social originário, amenizando a pressão que o mercado imobiliário possa exercer sobre a localidade: 
Mais do que nunca, nos assentamentos regularizados pela via da usucapião, é aconselhável gravar o território em processo de regularização como ZEIS, como forma de prevenção ao assédio do mercado imobiliário. As ZEIS gravam a área do assentamento como de interesse social, ou seja, a destinação do terreno, independentemente de quem esteja morando ali, é a habitação de interesse social, o que já induz à diminuição da vantagem da especulação imobiliária nessas áreas, pois o mecanismo reduz o valor do terreno. O Gravame das ZEIS, ao estabelecer parâmetros urbanísticos mais restritivos em relação ao tamanho dos lotes, bem como o coeficiente de aproveitamento e gabarito, naturalmente, diminui o interesse do mercado imobiliário sobre a área gravada. (ALFONSIN, B. in BRASIL, 2007b, p. 96) ${ }^{14}$

Guarda a mesma tônica a preocupação exarada por Venicio Salles (in NALINI e LEVY, 2013, p. 99):

Efetivamente, por se tratar de regularização fundiária, cujo propósito primeiro é fazer superar dificuldades da população de baixa renda para que esta camada populacional tenha acesso à propriedade privada, não há como se cobrar maior rigor na confecção do projeto ou no atendimento das exigências. Portanto, as disposições legais devem ser pensadas e lidas com uma carga de razoabilidade e flexibilização, própria do sentido da "função social da propriedade", relativizando o cumprimento das posturas urbanísticas e prescrições ambientais, desde que atendido o propósito da regularização, que é obter a melhoria ou o aprimoramento dos núcleos habitacionais implantados e consolidados.

Poder-se-ia aprofundar o acertado argumento, afirmando-se que, na sua vertente urbanística, o condomínio especial resultante da usucapião coletiva enseja o equivalente à delimitação judicial de uma Zona Especial de Interesse Social, verdadeiro condomínio especial de interesse social, a despeito de não expressamente nominado em lei e ainda que, a rigor, não se venha conferindo ao Poder Judiciário a prerrogativa regulatória em substituição ao

\footnotetext{
${ }^{14}$ No mesmo diapasão, Rafael GONÇALVES (2009) comenta: "A área, alvo da regularização fundiária, deve, frequentemente, ser declarada Zona Especial de Interesse Social (ZEIS) por uma lei municipal. Essa ferramenta jurídica prevê a possibilidade de flexibilizar localmente as diferentes regras urbanísticas, quando interesses sociais se impõem. O emprego das ZEIS põe fim à ideia, frequentemente retomada pelas autoridades públicas, de que elas não poderiam instalar serviços públicos nas favelas, em razão da ilegalidade urbanística e fundiária desses espaços. O fato de declarar uma zona ZEIS permite um controle mais restrito dos poderes públicos sobre as utilizações sociais desses espaços que são, doravante, destinados prioritariamente à habitação de interesse social. (...) Nesse contexto, a regularização fundiária deve ser compreendida não somente como um meio de suprimir o status fundiário ilegal dos espaços favelados, mas sobretudo como um meio de garantir a inclusão socioespacial das populações faveladas no tecido urbano. (...) Por sua vez, a regularização fundiária, como já vimos, pode legalizar o solo, mas reforçar a exclusão da população beneficiada, quando não se preveem mecanismos para desestimular uma excessiva valorização imobiliária. Aproveitando-se da mais-valia fundiária, obtida a partir da concessão de títulos de propriedade, certos moradores vendem muitas vezes suas moradias e se deslocam para outras favelas, em geral ainda mais precárias e distantes. Como já ressaltamos antes, novos instrumentos urbanísticos e jurídicos, como a Zeis, a UEU e/ou a Cuem podem atenuar esse processo."
} 
Executivo $^{15}$. Defender o contrário, há que se repisar, levaria ao absurdo de se inviabilizar a regularização de assentamentos populares já detentores dos direitos de propriedade do solo por infringência do zoneamento ou das posturas municipais, destacadamente quando não houver vontade política da Administração Pública para proceder, de ofício, a este ajuste de regulação. Não é este, decerto, o espírito da norma. Basta remontar à legislação de regência esparsamente positivada no ordenamento brasileiro para identificar respaldo a este recurso jurídico em favor do direito à moradia:

Lei n. 6766/79, art. $4^{\circ}$. (...) II - os lotes terão área mínima de $125 \mathrm{~m}^{2}$ (cento e vinte e cinco metros quadrados) e frente mínima de 5 (cinco) metros, salvo quando o loteamento se destinar a urbanização específica ou edificação de conjuntos habitacionais de interesse social, previamente aprovados pelos órgãos públicos competentes;

Lei n. 11.977/2009, art. 54. O projeto de regularização fundiária de interesse social deverá considerar as características da ocupação e da área ocupada para definir parâmetros urbanísticos e ambientais específicos, além de identificar os lotes, as vias de circulação e as áreas destinadas a uso público.

Infere-se que o processo de regularização fundiária de famílias de baixa renda realizado por intermédio da usucapião coletiva urbana também deva permitir, ou melhor, tenha por consequência lógica, a flexibilização dos parâmetros urbanísticos incidentes sobre a área adquirida pela comunidade de famílias, nos moldes da regularização de interesse social alçada na legislação federal contemporânea, sob pena de se fomentar ainda maior "informalização" das edificações promovidas e dos negócios jurídicos entabulados após a sentença ${ }^{16}$. Atentando para a questão, novos elementos vieram, em anos recentes, densificar o conteúdo do direito à cidade e, no mesmo giro, da usucapião especial urbana, como um dos caminhos para sua concreção.

15 A título ilustrativo, citamos: "EMENTA: DREITO URBANÍSTICO. ZONEAMENTO. ALTERAÇÃO. COMPETÊNCIA MUNICIPAL. 1. Compete ao Poder Público Municipal executar a política de desenvolvimento urbano para garantir o bem-estar da população. Artigo 182 da Constituição de República. 2. O zoneamento ambiental é um dos instrumentos postos à disposição do Município para a organização do espaço público. É vedado ao Poder Judiciário obrigar o Município a elaborar projeto de lei propondo a alteração do zoneamento de determinada região, sob pena de violação ao princípio da independência entre os poderes." (TJRS. 22ạ Câmara Cível. Apelação Cível n. 70038311718. Relatora: Desembargadora Maria Isabel de Azevedo Souza. Julgamento: 14 de outubro de 2010).

16 "A indivisibilidade do condomínio, significando a vedação à alienação do imóvel é um outro problema, pois poderá estimular a "informalização" das operações imobiliárias, que a regularização fundiária visava justamente a eliminar. (...) Da mesma maneira, serão necessários ajustes na legislação federal concernente aos deveres e obrigações resultantes da propriedade condominial a fim de adaptá-la à realidade social deste segmento social específico. Caberá às administrações municipais prestar esclarecimentos aos moradores para que compreendam as vantagens e desvantagens do condomínio e, assim, possam livremente decidir pela ação de usucapião coletivo ou optar por outra forma de regularização fundiária." (COMPANS, 2003, p. 51/52). 


\section{Da obrigação do Poder Público de promover a regularização fundiária plena}

O caso da Sociedade Barracão também levante questionamentos sobre as demais obrigações para o Poder Público, na inteligência da Lei n. 6.766/79, como a referente à implantação de infraestrutura básica para as áreas gravadas como de interesse social:

Art. $2^{\circ}, \S 60 \mathrm{~A}$ infraestrutura básica dos parcelamentos situados nas zonas habitacionais declaradas por lei como de interesse social (ZHIS) consistirá, no mínimo, de:

I. vias de circulação;

II. escoamento das águas pluviais;

III. rede para o abastecimento de água potável; e

IV. soluções para o esgotamento sanitário e para a energia elétrica domiciliar.

A precariedade do assentamento em tela, que teve negados administrativamente, inclusive, os pedidos de ligação de água e luz para suas residências, apenas revertidos em sede judicial ${ }^{17}$, demanda postura proativa da municipalidade, juntamente com as concessionárias de serviços públicos. Pois, se é certo que o uso da medida da usucapião coletiva como matéria de

17 No Mandado de Segurança n. 0007087-61.2015.8.16.0004, impetrado pela Associação de Catadores e Catadoras de Materiais Recicláveis Sociedade Barracão - Região Metropolitana de Curitiba, face à Companhia de Saneamento do Paraná (SANEPAR), determinou o juízo da 1a Vara da Fazenda Pública de Curitiba, em 21 março de 2016, fosse instalado o serviço de abastecimento de água, individualmente, ainda que não se houvesse procedido ao desmembramento das matrículas do condomínio especial constituído pela usucapião coletiva: "Desta forma, as concessionárias, como fornecedoras de serviços de água e esgoto, são obrigadas a fornecer aos consumidores que se utilizam como destinatários finais (arts. $2^{\circ}, 3^{\circ}$ e 22 , do $(D C)$, serviços de forma adequada, eficiente, segura e, quanto aos serviços essenciais, de forma contínua. Por outro lado, ainda possam ser estabelecidas exigências para a instalação do serviço, denota-se que está sendo exigida prova da propriedade do imóvel, mediante certidão da matrícula. Infere-se da sentença proferida na Ação de Usucapião (item 24.3), que houve declaração de domínio em comum, sem estabelecer o percentual do imóvel de cada qual porque não era possível identificar os moradores. Logo, o domínio que seria possível aos associados comprovar, seria uma única matrícula de toda área indivisa, pois enquanto não houver demarcação e divisão entre os condôminos, o domínio da área total foi assegurado de forma comum, e não individualizada. Todavia, com a declaração do domínio, cujos recursos interpostos não têm efeito suspensivo (item 24.4), ocasião em que somente não houve individualização de cada área porque se considerou necessária a identificação atual dos atuais possuidores, foi reconhecido o exercício da posse mansa, pacífica e ininterrupta. A posse do imóvel, cuja individualização decorre da circunstância de existirem construídas moradias, revela-se, suficiente para assegurar a instalação do serviço essencial, não de forma coletiva e provisória, mas, sim, individualizada e definitiva, pois a prestação do serviço essencial independe do domínio do consumidor. Ao consumidor, como destinatário do serviço, ainda que não seja titular do domínio, exercendo a posse, com residência no local onde necessita do serviço, deve ser assegurada a instalação, cuja recusa viola à dignidade humana. Como serviço essencial, deve ser assegurado pelo ente público, notadamente porque necessário para salvaguarda da dignidade humana e do direito à saúde. Sendo morador do imóvel onde o serviço é essencial, deve ser assegurada condição de moradia digna, ainda que não possa comprovar o domínio. A prova de domínio, mediante certidão da matrícula do imóvel, não pode ser motivação de recusa da prestação do serviço essencial, pois a relação que se constituíra com o consumidor, é absolutamente alheia à discussão envolvendo o domínio (Usucapião)". Por sua vez, a disputa segue em torno do fornecimento de energia elétrica, estando em curso, junto ao TJPR, a Apelação Cível 000708324.2015.8.16.0001 em face da Companhia Paranaense de Energia (COPEL). 
defesa em sede de ação possessória garante às famílias a segurança da posse, elemento essencial do direito à moradia, o mesmo não é tão pacífico, ainda, para as demais dimensões desse direito.

O feixe de posições jurídicas encampado sob o guarda-chuva desse direito social de terceira geração é complexo e sua integralidade pressupõe a observância de outras dimensões, como o acesso à infraestrutura básica, condições dignas de habitabilidade, mobilidade, disponibilidade de serviços e equipamentos públicos, adequação cultural e compatibilidade da renda, destrinchados no Comentário Geral n. 04 das Nações Unidas ao Pacto Internacional dos Direitos Humanos Econômicos, Sociais e Culturais. Tais condições somente serão asseguradas com o advento da urbanização posterior, a cargo do Estado, como o devedor por excelência da faceta prestacional do direito fundamental à moradia. Perfilha essa opinião Cordeiro:

A urbanização do condomínio especial do Estatuto da Cidade, em regra, é obrigação do Poder Público. Contudo, a sua realização poderá ser permitida aos próprios moradores ou mesmo à iniciativa privada, contando que seja observada a legislação aplicável à espécie, notadamente o regramento do plano diretor. Aliás, apesar da ocupação originária dos usucapientes não se caracterizar como um parcelamento do solo urbano, nos termos da Lei n. 6.766/79, tem-se que a infraestrutura básica prevista na referida lei também deverá ser implantada no condomínio especial do Estatuto da Cidade, ou seja, canalização de água potável, esgoto, vias de circulação, energia elétrica, escoamento de águas pluviais ( $\$ 50$ e $\S 60$ do art. 20 da Lei n. 6.766/79). (CORDEIRO, 2011, p. 249)

O condomínio especial de interesse social é, assim vislumbrado, forma de propriedade resolúvel (porque já nasce tendente à extinção, ressalvadas situações excepcionais), tendo por condição resolutiva a completa regularização fundiária do assentamento a ser empreendida pelo Poder Público, depois do que se poderão desmembrar os lotes relativos a cada morador. Resta, prima facie, ao Município a obrigação de promover a urbanização da área coletivamente usucapida, nos moldes do parcelamento de interesse social da Lei n. 6.766/79 ou da regularização fundiária de símile teor consignada na Lei n. 11.977/09. A inteligência conjugada dos art. 47, VII, 'a', art. 50, I ou II, e art. 55 deste diploma basta para sustentar o dever estatal de urbanização (implantação de sistema viário e infraestrutura básica) em áreas de ocupação de mais de cinco anos de posse, ainda quando os atos da regularização fundiária de interesse social, em nível dominial, sejam promovidos coletivamente pelos próprios interessados, diretamente ou representados por pessoas jurídicas legitimadas:

Art. 47, VII - regularização fundiária de interesse social: regularização fundiária de assentamentos irregulares ocupados, predominantemente, por população de baixa renda, nos casos: 
a. em que a área esteja ocupada, de forma mansa e pacífica, há, pelo menos, 5 (cinco) anos; (...)

Art. 50. A regularização fundiária poderá ser promovida pela União, pelos Estados, pelo Distrito Federal e pelos Municípios e também por:

I. seus beneficiários, individual ou coletivamente; e

II. cooperativas habitacionais, associações de moradores, fundações, organizações sociais, organizações da sociedade civil de interesse público ou outras associações civis que tenham por finalidade atividades nas áreas de desenvolvimento urbano ou regularização fundiária.

Parágrafo único. Os legitimados previstos no caput poderão promover todos os atos necessários à regularização fundiária, inclusive os atos de registro. (...)

Art. 55. Na regularização fundiária de interesse social, caberá ao poder público, diretamente ou por meio de seus concessionários ou permissionários de serviços públicos, a implantação do sistema viário e da infraestrutura básica, previstos no $\underline{\S 0}$ do art. $2^{\circ}$ da Lei ํㅡㄴ.766, de 19 de dezembro de 1979 , ainda que promovida pelos legitimados previstos nos incisos I e ll do art. 50.

Registre-se, ainda, que o êxito da ação de usucapião supre, a nosso ver, a necessidade de prova quanto ao grau de consolidação do assentamento, um dos requisitos inscritos no art. 54, §1으 da Lei n. 11.977/09 para assentamentos informais inseridos em Áreas de Preservação Permanente. Essa interpretação contribuiria em muito para melhor administrar conflitos socioambientais que se acirram visivelmente nas grandes cidades brasileiras, acarretando intervenção obrigatória do Poder Público.

É, sob determinadas circunstâncias, compreensível a cautela dos órgãos responsáveis quanto à urbanização em caráter definitivo de assentamento cujos terrenos se achem sub judice, pelo próprio risco da incorporação dos investimentos realizados ao patrimônio do proprietário formal, em saindo este vitorioso do processo. Paralelamente, as intervenções deste tipo, por responderem a outras dinâmicas e temporalidades pouco compatíveis com o ritmo e os rumos da ação judicial, podem implicar em deslocamento dos moradores, chegando a afetar a disputa possessória, razão pela qual tampouco se mostraria aconselhável urbanizar a área simultaneamente ao curso da ação ${ }^{18}$. Todavia, tão logo superada a pendência dominial, já não

\footnotetext{
18 "Segundo muitos observadores, outra questão que merece destaque, por continuar inexplicável para as comunidades envolvidas no Processo de Regularização Fundiária, é o de como as obras acontecem em descompasso com a regularização da posse da terra. E, aqui, a pesquisa ilustra situações em que, novamente, nos deparamos com uma intervenção urbanística que contempla, senão toda, boa parte do núcleo envolvido, e uma intervenção jurídica que contempla situações individualizadas. Obras são dinâmicas. A regularização da posse é morosa. Obras atendem a todo o núcleo, são visíveis, a regularização da terra é individualizada. Essas questões deixam mais evidente a necessidade de adoção de institutos como o da usucapião coletiva ou das ações plúrimas de usucapião para efeitos de regularização da posse da terra, não desmobilizando as pessoas que se organizam em função de problemas coletivos." (SILVA, 2005, p. 104-5)
} 
sobrevive fundamento para a recusa. Ademais, sendo a regularização fundiária direito subjetivo dos ocupantes, natural que a urbanização caracterize ato vinculado e não meramente discricionário do gestor:

O que acontece é que hoje não se pode mais falar de regularização fundiária tão-somente como sendo algo que se encontra no âmbito da ação discricionária do poder público, que a faz quando quer, de acordo com os critérios que acha que deve seguir, quando for pressionado pela população ou quando tiver compromissos políticos com a população. Existe juridicamente constituído no Brasil hoje um direito subjetivo do ocupante à regularização, em condições especificadas na lei, e isso mesmo contra a vontade do poder público. (FERNANDES in FERNANDES e ALFONSIN, 2006, p. 16)

Não é inusitada a ideia de que a regularização fundiária de interesse social seja solução com prioridade absoluta sobre o reassentamento, substituível por este apenas quando se mostre, de plano, inviável a fixação das famílias, do ponto de vista da melhor proteção ao direito à moradia digna. Tal primado foi consagrado na Lei n. 10.257/2001, passando a reger a nova ordem jurídico-urbanística pátria, e reverte, pela via reflexa, em estreitamento do poder discricionário do administrador, no momento de eleição das medidas adequadas para atendimento habitacional. O fato de que o interesse social integra o interesse público primário, preponderando sobre o interesse público secundário ${ }^{19}$ (diga-se, o interesse ou a interpretação da Administração Pública), deriva do grau de vinculação das decisões governamentais às diretrizes da política urbana, sendo o bloco de princípios constitucionais o fiel desta balança, na lição de Binenbojm:

A emergência da noção de juridicidade administrativa, com a vinculação direta da Administração à Constituição, não mais permite falar, tecnicamente, numa autêntica dicotomia entre os atos vinculados e atos discricionários, mas, isto sim, em diferentes graus de vinculação dos atos administrativos à juridicidade. (...) como se vê, essa principialização do direito brasileiro acabou por aumentar a margem de vinculação dos atos discricionários à juridicidade. Em outras palavras, essa nova concepção de discricionariedade vinculada à ordem jurídica como um todo, trouxe a percepção de que não há diferença de natureza entre o "ato administrativo vinculado" e o "ato administrativo discricionário", sendo a diferença o grau de vinculação. (BINENBOJM, 2008, p. 208)

19 "Para aqueles que adotam a distinção, feita por Renato Alessi, entre interesse público primário e interesse público secundário, o segundo acaba sendo conceituado como o modo pelo qual os órgãos da Administração interpretam o interesse público, enquanto o primeiro é identificado como o bem geral, sendo sinônimo de interesse social. (...) De modo menos utópico, diríamos que sujeitos do interesse social podem ser parcelas significativas da coletividade (não, necessariamente, toda ela), preservada, porém, a indeterminação das pessoas que as integram (pois do contrário ingressaríamos na órbita do interesse coletivo)." (FERRAZ, 2010, P. 37-8) 
Tanto é assim que, na hipótese de desapropriação judicial por interesse social do art. 1.228, §4ำ e §5으, do Código Civil de 2002, aparentada, ao menos finalisticamente, à usucapião especial coletiva, a Administração Pública encontra-se, quando houver intervido de alguma forma na lide, adstrita à execução da política de reforma urbana, suportando inclusive a indenização a ser paga, em virtude da supremacia do bem jurídico constitucionalmente albergado, qual seja, o direito à moradia. Essa a abalizada conclusão das Jornadas de Direito Civil a respeito:

ENUNCIADO 304: São aplicáveis as disposições dos §§ 4으 e 5임 do art. 1.228 do Código Civil às ações reivindicatórias relativas a bens públicos dominicais, mantido, parcialmente, o Enunciado 83 da I Jornada de Direito Civil, no que concerne às demais classificações dos bens públicos. ENUNCIADO 308: A justa indenização devida ao proprietário em caso de desapropriação judicial (art. 1.228, §5ㅇ) somente deverá ser suportada pela Administração Pública no contexto das políticas públicas de reforma urbana ou agrária, em se tratando de possuidores de baixa renda e desde que tenha havido intervenção daquela nos termos da lei processual. Não sendo os possuidores de baixa renda, aplica-se a orientação do Enunciado 84 da I Jornada de Direito Civil.

ENUNCIADO 310: Interpreta-se extensivamente a expressão "imóvel reivindicado" (art. 1.228, §4ㅇ), abrangendo pretensões tanto no juízo petitório quanto no possessório.

Impende submeter ao mesmo funcionamento a decisão que declara a aquisição de copropriedade pela via da usucapião especial urbana coletiva, vinculando o Poder Público à consecução da regularização fundiária plena, como corolário da política urbana, fazendo uso, se necessário for, dos instrumentos de planejamento e gestão territorial e orçamentária, em observância ao regime de supremacia do interesse social.

\section{(IN)CONCLUSÕES: DO DIREITO DA CIDADE AO DIREITO À CIDADE}

Da breve exposição que se envidou de dois casos concretos de utilização da usucapião especial urbana como instrumento de regularização fundiária no Município de Curitiba podemse extrair reflexões de ordem propriamente jurídica, como política.

No âmbito dogmático, subsiste ainda uma tensão irresoluta entre as pretensões individuais e os trâmites coletivos inerentes a esta espécie de ação. Se a miopia de nossa legislação processual civil em matéria de demandas plúrimas é patente, devemos destacar também alguns questionamentos de direito material, nesta seara.

Verifica-se, na fase de pré-ajuizamento, que o principal fator a compelir as comunidades de baixa renda à utilização da via coletiva é a ausência de individualização da posse, requisito 
que deve ser entendido antes como a impossibilidade de delimitação formal de cada lote ocupado, do que somente em sua expressão muito particular de confusão construtiva, a qual não contempla todo o espectro de morfologias presentes nos assentamentos informais. Outrossim, recentes julgados têm estabelecido vinculação exorbitante entre o prévio parcelamento do solo, nos termos da Lei n. 6.766/1979, e os institutos da Lei n. 10.257/2001, restringindo o âmbito de aplicação prática da usucapião especial urbana e reforçando a necessidade de se privilegiar, quanto possível, a modalidade coletiva, preferencialmente abrangendo a totalidade do assentamento.

Por sua vez, a indivisibilidade do condomínio especial instituído com a sentença que declara a usucapião tende a gerar conflitos na administração do imóvel, agravados pela mora e burocracia do processo de subdivisão em imóveis unitários. Não é de hoje que autores como Betânia Alfonsin vêm chamando atenção para os embates que afloram no momento da adequação urbanística do assentamento. Diante das divergências nesta etapa, a mediação entre os interesse coletivos e individuais/setoriais ganha centralidade, conjugada sempre a estratégias de gestão territorial participativa:

Como se tratam de posses, um direito real individual de cada posseiro que lhe dá a expectativa de vir a ser proprietário do lote que ocupa como se dono fosse, torna-se bastante delicada a proposição de estudos de viabilidade urbanística que corrijam distorções no sistema espacial do assentamento. De fato, um trabalho de convencimento político muito bem feito é necessário para que a regularização não empaque na resistência dos moradores em ceder parte de seus lotes para que a coletividade tenha vias de acesso minimamente adequados, por exemplo. Alguém poderia indagar do direito de indenização dos moradores de lotes atingidos pelo projeto de urbanização e, não tenho dúvidas de que é uma indagação procedente. Parece que a questão tem de ser equacionada caso a caso, sem o estabelecimento de uma regra geral que tenha de ser aplicada sem atenção ao caso concreto. Há o bom senso, a opinião e a participação da comunidade como um todo (não apenas dos moradores objetivamente prejudicados) e o incremento da qualidade de vida como fatores importantes a serem considerados/observados para resolver essas questões. Parece-me que tanto pode ser adotado um sistema de indenização como eventualmente, pelo desejo maior de regularizar o assentamento, a comunidade pode abrir mão desse direito através de um consenso. A negociação com a população beneficiária é fundamental nos processos de regularização fundiária, sobremaneira, nos casos em que a ocupação se deu em uma área privada e gerou direito à Usucapião. (ALFONSIN, 2010, p. 26)

Se na sua fase judicial o processo de regularização fundiária pode se ter iniciado de maneira unilateral, por incitação dos possuidores, suas etapas subsequentes deverão ser norteadas por metodologias de participação popular e diálogo entre saberes: 
Nesse sentido, ainda há muitos caminhos a percorrer à medida que, em alguns momentos, as prioridades dos representantes do poder público colidem com as demandas locais populares, tendo em vista que as formações dos profissionais que estão à frente do processo estão ligadas a uma área mais técnica e, com isso, encontram dificuldades em compreender o funcionamento dos princípios da democracia participativas que estão se efetivando na prática. (DIAS e BOGUS, 2010, p. 453)

A propósito, os avanços legislativos em matéria de regularização fundiária de interesse social, precipuamente as inovações acolhidas pelas Leis n. 11.977/2009 e 12.651/2012 (Novo Código Florestal), tiveram o condão de reposicionar toda a constelação de instrumentos urbanísticos do Estatuto da Cidade, inclusive a usucapião especial. O giro hermenêutico que hora cabe à doutrina e à jurisprudência operar diz respeito à lapidação do instituto, assegurando-Ihe aplicabilidade, ampliando-Ihe o escopo e conferindo-Ihe efetividade dentro do paradigma da nova ordem jurídico-urbanística nacional. Balizar o regime jurídico do condomínio especial pós-sentença, por exemplo, é uma das tarefas urgentes, ativando noções como a de discricionariedade mitigada e de juridicidade administrativa para controlar a tentação da arbitrariedade em que pode o Poder Público incorrer, obstando o processo de regularização fundiária.

Dúvida não resta de que institutos como a demarcação urbanística e a legitimação da posse são sobremaneira bem-vindos, elastecendo o leque de medidas curativas franqueadas aos gestores. Ao lado da usucapião especial urbana, cujo modo de aquisição de propriedade é originária e gratuita, esse ferramental poderá agilizar e reduzir consideravelmente o custo das políticas e programas de regularização. Nada obstante, é a usucapião coletiva que remanesce como uma das poucas alternativas para que os moradores de assentamentos informais tornemse protagonistas dos processos de regularização fundiária, em face da ausência de vontade política ${ }^{20}$ ou do déficit técnico dos atores estatais para tanto. Outrossim, o seu manejo, ao sobrestar automaticamente demais investidas judiciais que venham a ameaçar a estabilidade da ocupação, por força do art. 12 da Lei n. 10.257/2001, presta-se a salvaguardar a segurança jurídica da posse, oferecendo certo tempo e confiança necessários à boa condução de eventuais negociações junto ao Poder Público. Nesse contexto, o uso do instrumento em comento pode

\footnotetext{
${ }^{20}$ Ressalte-se que o largo prazo necessário à conclusão das ações de regularização fundiária amiúde expõe a própria intervenção às soluções de continuidade das gestões políticas: "Outro problema encontrado pela municipalidade para a implementação de suas políticas urbanas é a descontinuidade administrativa. Assim, os chefes do governo eu se sucedem no poder municipal não têm necessariamente a mesma visão sobre os problemas urbanos e as prioridades a serem enfrentadas." (IMPARATO, 1999, p. 232).
} 
vir a integrar uma estratégia maior, contrapondo-se ao cenário de acentuado clientelismo político que grassa nas cidades brasileiras e que dá azo à manipulação e ao silenciamento das comunidades vulnerabilizadas por uma correlação desigual de forças.

Conquanto a própria dificuldade de acesso à justiça a que essas populações têm de fazer frente (elevado custo de contratação de advogados, morosidade do processo judicial, risco de resultado final desfavorável) desestimule, no mais das vezes, o recurso à judicialização, experiências exitosas de defesa do direito à moradia vêm à tona, como a do Morro Santa Teresa, em Porto Alegre. Esse sucesso depende, para além da técnica jurídica, da articulação de uma rede de atores sociais em torno do conflito:

O conflito oportunizou a emergência de um ativismo social bastante rico, articulando distintos atores a partir de uma determinada territorialidade e de uma problemática ancorada espacialmente. Além disso, a produtividade jurídica do processo foi inequívoca, implodindo antigas interpretações do Direito Civil e Administrativo brasileiro. (...). Finalmente, as articulações políticas e sociais surgidas ao longo do processo, marcadas por inéditas coalizões entre ativismos sociais de origens e objetos distintos, foram capazes de colocar em marcha uma estratégia política vitoriosa, em que atores contra hegemônicos disputaram a opinião pública e foram capazes de derrotar grupos hegemônicos com muito maior poder econômico e político. (ALFONSIN, CAFRUNE e KONZEN, 2013, p. 233)

Como contraponto que não se pode ignorar, ressoam críticas a este tipo de judicialização da política urbana, com dúvidas sobre a real vocação do Poder Judiciário para administrar conflitos dessa envergadura. O debate é árido e envolve desde fatores de capacidade institucional e formação acadêmica, até a defasagem do arcabouço legal atualmente disponível. Assim mesmo, acreditamos que não se deve descartar certo nível de politização da justiça imbricado no mesmo movimento, como sinalizada Santos:

A judicialização da política verifica-se ainda diante de um conjunto de circunstâncias que descentraram a atenção da política judiciária para a política do judiciário. Neste caso, o confronto político do judiciário com os outros poderes do Estado dá-se quando, diante da apatia ou da incapacidade dos poderes públicos em resolver conflitos ou em atender às demandas dos grupos sociais, o recurso aos tribunais leva o judiciário a interferir na política pública e nas condições da sua efetivação. Neste caminho, o sistema judicial torna-se ferramenta estrategicamente utilizada pelos grupos em disputa e partidos políticos para frear ou vetar a implementação da agenda política governamental ou dos grupos políticos maioritários. Para além do impacto no sistema político, a judicialização da política afeta também o desempenho dos próprios tribunais, conduzindo à politização do judiciário. (SANTOS, 2007, p. 18)

É que, enfim, entre o individual e o coletivo, entre o judicial e o administrativo, a usucapião especial vai se desprendendo do berço privatista-patrimonialista em que foi forjada e 
se (re)plasmando à luz da axiologia intrínseca ao direito à cidade, direito este em permanente construção: o direito humano dos seres urbanos, ou vice-versa.

\section{REFERÊNCIAS BIBLIOGRÁFICAS}

ALFONSIN, B. Políticas de Regularização Fundiária: Justificação, Impactos e Sustentabilidade. Cambridge: Lincoln Institute Research Report, 2010.

ALFONSIN, Betânia; CAFRUNE, Marcelo Eibs e KONZEN, Lucas Pizzolato. O exercício do direito humano à moradia como estopim de mudanças jurídicas, políticas e territoriais: um estudo de caso em Porto Alegre. In FERNANDES, Edésio e ALFONSIN, Betânia (Coords.). Direito à moradia adequada: o que é, para quem serve, como defender e efetivar. Belo Horizonte: Fórum, 2013

BINENBOJM, G. Uma Teoria do Direito Administrativo - Direitos Fundamentais, Democracia e Constitucionalização. 2a edição. Rio de Janeiro: 2008

BRASIL. Manual da regularização fundiária plena. Brasília: Ministério das Cidades, 2007a.

Regularização fundiária sustentável - conceitos e diretrizes. Brasília: Ministério das Cidades, 2007b.

Ações Integradas de Urbanização de Assentamentos Precários - Edição Bilíngue. Brasília/São Paulo: Ministério das Cidades/Aliança de Cidades, 2010.

CAMPOS, Andrelino. Do Quilombo à Favela: a produção do "espaço criminalizao no Rio de Janeiro. Rio de Janeiro: Bertrand Brasil, 2005.

COMPANS, R. A regularização fundiária de favelas no Estado do Rio de Janeiro. In Revista Rio de Janeiro, n. 9, p. 41-53, jan./abr. 2003.

CORDEIRO, C. J. Usucapião especial urbano coletivo: abordagem sobre o Estatuto da Cidade. Belo Horizonte: Del Rey, 2011.

DAVIS, M. Planeta Favela. São Paulo: Boitempo, 2006.

DIAS, J. M. P. e BÓGUS, L. Regularização Fundiária Urbana Participativa: a experiência do loteamento Ponte Alta "Osvaldinho" no Município de Taboão da Serra. In: BÓGUS, L.; RAPOSO, I. e PASTERNAK, S. (Orgs.). Da irregularidade fundiária urbana à regularização: análise comparativa Portugal-Brasil. São Paulo: EDUC, 2010.

FERNANDES, E. Regularização de Assentamentos Informais na América Latina. Cambridge: Lincoln Institute of Land Policy, 2011.

FERNANDES, E. e ALFOSIN, B. (Orgs.). Direito Urbanístico: estudos brasileiros e internacionais. Belo Horizonte: Del Rey, 2006.

FERRAZ, A. A. M. de C. Considerações sobre interesse social e interesse difuso. In: Revista Internacional de Direito e Cidadania, n. 6, p. 33-46, fevereiro/2010, p. 37-38 
GONÇALVES, R. Repensar a regularização fundiária como política de integração socioespacial. In ESTUDOS AVANÇADOS Vol. 23, no 66, 2009, disponível em http://www.scielo.br

IMPARATO, E. O usucapião constitucional urbano. In: SAULE JÚNIOR, N. (Coord.). Direito à Cidade: trilhas legais para o direito às cidades sustentáveis. São Paulo: Instituto Pólis/Max Limonad, 1999.

LOUREIRO, F. Direito à moradia e Segurança da Posse no Estatuto da Cidade. São Paulo: Editora Fórum, 2004.

MATTOS, Liana Portilho. Nova Ordem Jurídico-Urbanística: Função Social da Propriedade na Prática dos Tribunais. Rio de Janeiro: Lumen Juris, 2006.

NALINI, J. R. Direitos que a cidade esqueceu. São Paulo: Editora Revista dos Tribunais, 2011, p. 170.

NALINI, J. R. e LEVY, W. (Coords). Regularização Fundiária. 2ạ ed. Rio de Janeiro: Forense, 2013.

SANTOS, B. S. Para uma revolução democrática da justiça. 3ạ Ed. São Paulo: Editora Cortez, 2007

SAULE JUNIOR, N. A proteção jurídica da moradia nos assentamentos irregulares. Porto Alegre: Sergio Antônio Fabris Editor, 2004.

SILVA, J. S. Irregularidade fundiária e usucapião especial urbana: ruptura com a tradição jurídica de proteção à propriedade privada? A experiência de Porto Alegre (1989-2004). Dissertação de mestrado apresentada ao programa de Pós-Graduação em Planejamento Urbano e Regional da Faculdade de Arquitetura da Universidade Federal do Rio Grande do Sul. Porto Alegre: 2005.

VALLADARES, Licia do Prado. A invenção da favela: do mito de origem a favela.com. Rio de Janeiro: FGV, 2005.

Legislação

BRASIL. Lei n. 4.591/64, de 16 de dezembro de 1964. Dispõe sôbre o condomínio em edificações e as incorporações imobiliárias. Disponível em: http://www.planalto.gov.br/ccivil_03/leis/L4591.htm. Acesso em: 16 de junho de 2016.

Lei 6.766, de 19 de dezembro de 1979. Dispõe sobre o Parcelamento do Solo Urbano e dá outras Providências. Disponível em: <http://www.planalto.gov.br/ccivil_03/leis/L6766.htm>. Acesso em: 15 de junho de 2016.

Lei 10.257 , de 10 de julho de 2001. Regulamenta os arts. 182 e 183 da Constituição Federal, estabelece diretrizes gerais da política urbana e dá outras providências. Disponível em: <http://www.planalto.gov.br/ccivil_03/leis/LEIS_2001/L10257.htm>. Acesso em: 16 de junho de 2016.

Lei 10.406, de 10 de janeiro de 2002. Institui o Código Civil. Disponível em: <http://www.planalto.gov.br/ccivil_03/leis/2002/L10406.htm>. Acesso em: 15 de junho de 2016.

Lei 11.977 de 7 de julho de 2009. Dispõe sobre o Programa Minha Casa, Minha Vida PMCMV e a regularização fundiária de assentamentos localizados em áreas urbanas; altera o 
Decreto-Lei no 3.365, de 21 de junho de 1941, as Leis nos 4.380, de 21 de agosto de 1964, 6.015, de 31 de dezembro de 1973, 8.036, de 11 de maio de 1990, e 10.257, de 10 de julho de 2001, e a Medida Provisória no 2.197-43, de 24 de agosto de 2001; e dá outras providências. Disponível em: <http://www.planalto.gov.br/ccivil_03/_ato2007-2010/2009/lei/l11977.htm>. Acesso em: 15 de junho de 2016.

Lei 12.651, de 25 de maio de 2012. Dispõe sobre a proteção da vegetação nativa; altera as Leis nํ 6.938, de 31 de agosto de 1981, 9.393, de 19 de dezembro de 1996, e 11.428, de 22 de dezembro de 2006; revoga as Leis nos 4.771, de 15 de setembro de 1965, e 7.754, de 14 de abril de 1989, e a Medida Provisória no 2.166-67, de 24 de agosto de 2001; e dá outras providências. Disponível em: <http://www.planalto.gov.br/ccivil_03/_ato2011-2014/2012/lei/l12651.htm> . Acesso em: 14 de junho de 2016.

Medida Provisória 759, de 22 de dezembro de 2016. Dispõe sobre a regularização fundiária rural e urbana, sobre a liquidação de créditos concedidos aos assentados da reforma agrária e sobre a regularização fundiária no âmbito da Amazônia Legal, institui mecanismos para aprimorar a eficiência dos procedimentos de alienação de imóveis da União, e dá outras providências. Disponível em: < http://www.planalto.gov.br/ccivil_03/_ato20152018/2016/Mpv/mpv759.htm>. Acesso em: 22 abril de 2017.

Trabalho enviado em 22 de fevereiro de 2017.

Aceito em 09 de maio de 2017. 